MISS MOLLY-ANN WILLIAMS (Orcid ID : 0000-0002-7795-8001)

DR. ANNE PARLE-MCDERMOTT (Orcid ID : 0000-0002-1533-3209)

Article type : From the Cover

\title{
The application of CRISPR-Cas for single species identification from environmental DNA
}

\section{Using CRISPR-Cas to detect species from eDNA}

Molly-Ann Williams ${ }^{\mathrm{a}, \mathrm{c}, 1}$, Joyce 0’Grady,c, Bernard Balld, Jens Carlsson ${ }^{\mathrm{d}}$, Elvira de Eyto ${ }^{\mathrm{e}}$, Philip McGinnitye,f, Eleanor Jenningsg, Fiona Regan ${ }^{\mathrm{b}, \mathrm{c}}$, Anne Parle-McDermotta,c,1

aSchool of Biotechnology, Dublin City University, Dublin 9, Ireland; bSchool of Chemical Sciences, Dublin City University, Dublin 9, Ireland; 'DCU Water Institute, Dublin City University, Dublin 9, Ireland; dArea 52 Research Group, School of Biology and Environmental Science/Earth Institute, University College Dublin, Dublin 4, Ireland; eMarine Institute, Furnace, Newport, Co. Mayo, Ireland. fSchool of Biological, Earth \& Environmental Sciences, University College Cork, Cork, Ireland sCentre for Freshwater Studies and Department of Applied Sciences, Dundalk Institute of Technology, Dundalk, Ireland.

${ }^{1}$ To whom correspondence may be addressed. Email: molly.williams9@mail.dcu.ie or anne.parlemcdermott@dcu.ie

Keywords: freshwater, biosensor, environmental, Salmon, CRISPR-Cas, eDNA

This article has been accepted for publication and undergone full peer review but has not been through the copyediting, typesetting, pagination and proofreading process, which may lead to differences between this version and the Version of Record. Please cite this article as doi: 10.1111/1755-0998.13045

This article is protected by copyright. All rights reserved. 


\begin{abstract}
We report the first application of CRISPR-Cas technology to single species detection from environmental DNA (eDNA). Organisms shed and excrete DNA into their environment such as in skin cells and faeces, referred to as environmental DNA (eDNA). Utilising eDNA allows noninvasive monitoring with increased specificity and sensitivity. Current methods primarily employ PCR-based techniques to detect a given species from eDNA samples, posing a logistical challenge for on-site monitoring and potential adaptation to biosensor devices. We have developed an alternative method; coupling isothermal amplification to a CRISPR-Cas12a detection system. This utilises the collateral cleavage activity of Cas12a, a ribonuclease guided by a highly specific single CRISPR RNA. We used the target species Salmo salar as a proof-ofconcept test of the specificity of the assay among closely related species and to show the assay is successful at a single temperature of $37^{\circ} \mathrm{C}$ with signal detection at $535 \mathrm{nM}$. The specific assay, detects at attomolar sensitivity with rapid detection rates $(<2.5 \mathrm{~h})$. This approach simplifies the challenge of building a biosensor device for rapid target species detection in the field and can be easily adapted to detect any species from eDNA samples from a variety of sources enhancing the capabilities of eDNA as a tool for monitoring biodiversity.
\end{abstract}

\title{
Introduction
}

Environmental DNA (eDNA) offers a new opportunity for biologists and conservationists to monitor biodiversity and track invasive species from the organic material that they leave behind. The urgency of biodiversity monitoring is at an all-time high with the latest WWF Living Planet Index showing an overall decline of $60 \%$ in wildlife population sizes since 1970 , rising to 83\% for freshwater organisms (WWF, 2018). An organism can provide a rich source of eDNA in both soil and water through the cells and waste that they shed and excrete including faeces, mucus, gametes, hair and skin (Thomsen, Kielgast, Iversen, Wiuf, et al., 2012). As well as

This article is protected by copyright. All rights reserved. 
retrieving samples directly from the environment such as fresh or sea water, eDNA can also be collected from longer term deposits such as sediment and ice cores (Ficetola, Miaud, Pompanon, \& Taberlet, 2008; Jerde, Mahon, Chadderton, \& Lodge, 2011; Thomsen, Kielgast, Iversen, Møller, et al., 2012; Turner, Uy, \& Everhart, 2015; Willerslev et al., 2007). eDNA will improve biodiversity monitoring by providing data on the variety, geographic range (Beans, 2018) and potentially the abundance of species enabling greater ecosystem protection (Guisan et al., 2013). Species monitoring has traditionally relied on the sighting and often the capture of an organism of interest. The monitoring of fish in aquatic environments is challenging, requiring the collection of fish using electricity, the placement of fish traps, nets or rod catches provided by anglers (The Standing Scientific Committee on Salmon, 2016). These techniques can be expensive, labour intensive and potentially harmful to the species of interest (Snyder, 2003). Moreover, organisms present in low abundance are often missed by these methods due to their low capture probabilities (Magnuson, Benson, \& Mclain, 1994).

The coupling of eDNA with contemporary molecular methods allows biologists to either generate a biodiversity profile of an ecosystem using metabarcoding (Deiner et al., 2017) or to target and monitor a particular species using specific eDNA assays. Next generation sequencing technologies are driving developments in DNA metabarcoding (Shokralla, Spall, Gibson, \& Hajibabaei, 2012) and allow the potential identification of multiple species across all taxa from microbes to higher vertebrates and from either contemporary or ancient eDNA samples (Taberlet, Coissac, Pompanon, Brochmann, \& Willerslev, 2012). This includes the possibility of identifying microbes that previously would have required cultivation on an artificial medium or more critically could not be grown outside of their host and hence not amenable to identification using conventional methods (DeLong, 2005).

Quantitative PCR (qPCR) and digital droplet (dd) PCR are currently the main methods used to detect eDNA of focal species (Baker, Steel, Nieukirk, \& Klinck, 2018; Boothroyd, Mandrak, Fox, \& Wilson, 2016; Carlsson et al., 2017; Dejean et al., 2011; Gargan et al., 2017; Rusch et al., 2018;

This article is protected by copyright. All rights reserved. 
Thomsen, Kielgast, Iversen, Møller, et al., 2012; Uthicke, Lamare, \& Doyle, 2018). However, the need to cycle from $95^{\circ} \mathrm{C}$ to lower temperatures during the PCR process makes the adaptation of PCR-based techniques to a portable biosensor device challenging (Zhang \& Xing, 2007). All eDNA assays reported to date need to be processed in a specialised molecular laboratory with trained personnel, which excludes their use in the field. In seeking to develop a device for rapid, on-site monitoring of a target species using eDNA, our aim was to develop a molecular diagnostic technique that does not require PCR-based temperature cycling.

Here, as a proof of concept, CRISPR/Cas technology (Chen et al., 2018; Gootenberg et al., 2017), is deployed to identify Salmo salar from eDNA samples collected in Irish rivers, where presence or absence had been previously confirmed using conventional field sampling (Atkinson et al., 2018). The assay uniquely requires incubation at $37^{\circ} \mathrm{C}$ using fluorescence detection at $535 \mathrm{nM}$. Not only does employing CRISPR/Cas dramatically simplify the next challenge of building a biosensor device, it enhances the differential detection of closely related species and can be easily adapted to detect any species from eDNA samples from a variety of sources. To the best of the authors knowledge, this is the first application of this technology to eDNA.

\section{Materials and Methods}

Target site selection. In order to select a target site for the assay, mitochondrial sequences (SI Table S1) were obtained from GenBank Release 229.0 (NCBI) for Salmo salar, Salmo trutta (brown trout) and Salvelinus alpinus (Arctic char). These three species are members of the Salmonidae family which are indigenous to Ireland and are closely related to $S$. salar. Multiple sequence alignment of the complete mtDNA genome was performed using ClustalW alignment algorithm (Geneious 11.1.5). The alignment was visually scanned for regions whereby only $S$. salar contains the Cas12a 5'-TTTV-3' PAM site (Zetsche et al., 2015). Areas adjacent to appropriate PAM sites were scanned to ensure greatest number of mismatches between the $S$.

This article is protected by copyright. All rights reserved. 
salar sequence and the sequences of $S$. trutta and S. alpinus. The final target site selected resides within the NADH dehydrogenase subunit 5 gene. Intraspecific polymorphisms were assessed using single nucleotide polymorphism (SNP) data obtained from dbSNP Build 151 (NCBI) to ensure the assay would not be compromised by a polymorphism within the $S$. salar population. Selected primer and guide RNA sequences were subject to a BLAST 2.8.0 search (NCBI) to ensure they were specific to S. salar.

Recombinant DNA Cloning of salmonid sequences. PCR assays that target the mtDNA gene NADH dehydrogenase subunit 5 were designed and optimised for both S. salar and S. trutta. Our in silico analysis showed considerable differences at the target site in S. alpinus compared to $S$. salar and S. trutta and therefore, S. alpinus was excluded from further experimentation. Specific PCR products (SI Table S4) of $205 \mathrm{bp}$ and $225 \mathrm{bp}$ in size respectively, were cloned into a pUC19 vector using FastCloning (Li et al., 2011) with custom primers (SI Table S4). The FastCloning amplified and Dpn I digested products were transformed into OneShot ${ }^{\circledR}$ Top 10 chemically competent Escherichia coli cells (Invitrogen, USA) as per manufacturer's protocol. Recombinant clones were confirmed by Sanger cycle sequencing (Source Biosciences, IRL) using a custom primer, FastCloneCheck_F (SI Table S4).

Tissue DNA extraction. DNA was extracted from tissue samples from commercially available $S$. salar using DNeasy Blood and Tissue Kit (Qiagen, UK) following manufacturer's instructions. DNA from S. trutta (Burren River, Ireland) was extracted as previously described (Atkinson et al., 2018). To confirm species identity, the mitochondrial DNA Cytochrome Oxidase subunit I (COI) region was amplified and confirmed following Sanger sequencing (Source Biosciences, IRL) using previously published generic fish primers (Fish F1 and Fish R1) and conditions (Ward, Zemlak, Innes, Last, \& Hebert, 2005).

Environmental DNA preparation. Water samples from four Irish rivers were collected for eDNA analysis. Filtered eDNA extracts including negative field controls from Atkinson et al., (2018) were made available from the Burren, Dalligan and Delour rivers. At the Srahrevagh

This article is protected by copyright. All rights reserved. 
river, $550 \mathrm{ml}$ water samples were collected in sterilised $1 \mathrm{~L}$ Nalgene bottles and filtered through sterile $47 \mathrm{~mm}$ cellulose nitrate filters $(0.45 \mu \mathrm{m})$ using a vacuum. One negative control consisting of distilled water exposed to air was also filtered for each sampling session. Filters were cut in two and stored at $-20^{\circ} \mathrm{C}$. Environmental DNA was extracted from the filter using the Qiagen DNeasy Blood and Tissue kit with some modifications as in Renshaw, Olds, Jerde, McVeigh, \& Lodge (2015) and eluted in $50 \mu \mathrm{l}$ Buffer AE.

All work with eDNA was carried out in a dedicated Low Copy DNA laboratory to minimise potential contamination.

Cas12a detection assays. Alt-R Acidaminococcus sp. BV3L6 (A.s) Cas12a nuclease and crRNA (both synthesised commercially and purchased from IDT) complexes were preassembled by incubating $2.52 \mu \mathrm{M}$ A.s Cas12a with $3.2 \mu \mathrm{M}$ of a $S$. salar targeting crRNA in PBS at room temperature for 20 min. Recombinase Polymerase Amplification (RPA) products were generated using TwistAmp Basic (TwistDx). Briefly, $50 \mu \mathrm{l}$ reactions containing plasmid DNA at concentrations ranging from $8.4 \times 10^{-7}-84 \mathrm{ng} / \mu \mathrm{l}, 4 \mathrm{ng} / \mu \mathrm{l}$ tissue DNA or $1-20 \mathrm{ng} / \mu \mathrm{l}$ eDNA sample, $0.48 \mu \mathrm{M}$ forward and reverse primer, $1 \mathrm{x}$ rehydration buffer (TwistDx), $14 \mathrm{mM}$ magnesium acetate and RPA reaction pellet (TwistDx) were incubated at $37^{\circ} \mathrm{C}$ for 20 min with manual mixing after 4 min. Fluorescence assays were set up by diluting Cas12a-crRNA complexes to a final concentration of $50 \mathrm{nM}$ Cas12a: $62.5 \mathrm{nM}$ crRNA in a solution containing $1 \mathrm{x}$ Binding Buffer (20 mM Tris-HCL, pH 7.5, 100 mM KCl, 5 mM MgCl 2,1 mM DTT, 5 \% glycerol, 50 $\mu \mathrm{g} / \mathrm{ml}$ heparin), $50 \mathrm{nM}$ ssDNA-FQ reporter 5'-/56-FAM/TTATT/3IABkFQ/-3' (synthesised commercially and purchased from IDT) and either $2 \mu \mathrm{l}$ of RPA product or varying concentrations of plasmid DNA. Reactions $(20 \mu \mathrm{l}$, 96-well plate format) were incubated in a LightCycler 480 instrument (Roche) for $120 \mathrm{~min}$ at $37{ }^{\circ} \mathrm{C}$ with fluorescence measurements taken every $30 \sec (\lambda e x=485 \mathrm{~nm}$, $\lambda e m=535 \mathrm{~nm})$.

Statistical Analysis. Background-corrected fluorescence values were calculated by subtracting fluorescence values obtained from reactions carried out in the absence of target DNA. A

This article is protected by copyright. All rights reserved. 
threshold value for fluorescence was calculated as three standard deviations above background fluorescence, obtained from reactions carried out in the absence of target DNA $(n=3)$. Background noise may be present in the sample due to incomplete quenching of the fluorescent reporter. Only fluorescence values greater than this threshold value are considered as positive detection of target. A two-sample t-test assuming unequal variances was carried out to compare the fluorescence output of the test samples to the fluorescence values of the negative control at 120 minutes. Results are reported to indicate the relative level of the p-value whereby “*” indicates $\mathrm{p}<0.05$, “**” indicates $\mathrm{p}<0.01$ and “***” indicates $\mathrm{p}<0.001$.

\section{Results \& Discussion}

\section{CRISPR/Cas mediated species detection from eDNA}

The adaptation of CRISPR-Cas to a range of applications is expanding rapidly and is driven in the main by the identification and further characterisation of Cas nucleases and equivalent endonuclease enzymes to perform functions which go beyond genome editing (Barrangou \& Doudna, 2016). Recent studies have exploited the functionality of Cas12a (Barrangou \& Doudna, 2016). Cas12a, an RNA guided ribonuclease, functions similarly to the original genome editing Cas9 enzyme in that it binds a guide RNA that directs it to a specific sequence of DNA in order to catalyse a double stranded break. The guide RNA consists of a single crRNA region which is complementary to the target DNA (Fonfara, Richter, Bratovič, Le Rhun, \& Charpentier, 2016) and a scaffold region which interacts with the nuclease (Yamano et al., 2016). The Cas12a nuclease requires a T-rich protospacer adjacent motif (PAM) site (Zetsche et al., 2015) succeeding the crRNA target site in order to bind and cleave the target sequence. The additional functionality of Cas12a is that once it is bound to its target sequence, it gains an indiscriminate single stranded DNase activity that can be exploited for diagnostics (Chen et al., 2018). The collateral cleavage activity can be utilised for target detection through incorporation of a single stranded DNA fluorophore quencher (ssDNA-FQ) molecule with fluorescence only released upon cleavage by the Cas12a-crRNA-target site complex (Chen et al., 2018). This system of

This article is protected by copyright. All rights reserved. 
detection has proven to be a valid approach for the detection of clinical pathogens, but has not yet been considered for eDNA, despite offering the sensitivity, specificity and assay simplicity required for the detection of specific species from eDNA samples in a biosensor device. By coupling an isothermal amplification method known as Recombinase Polymerase Amplification (RPA) to a CRISPR-Cas detection system, both SHERLOCK (Gootenberg et al., 2017) and DETECTR (Chen et al., 2018) enable nucleic acid detection with attomolar sensitivity for clinical applications. This system also provides the potential for adaptation to a simplistic device with Gootenberg et al. (2018) developing a lateral flow system for visual readout of viral DNA detection.

Our application of CRISPR-Cas technology (DETECTR) for specific species detection from eDNA required the selection of a target species followed by assay design and the subsequent demonstration of this proof-of-concept. RPA-CRISPR-Cas technology can differentiate between closely related species due to three layers of sequence complementarity required. These include the primers for RPA, the binding sequence of the crRNA itself and the requirement for a T-rich sequence known as PAM that must proceed the crRNA target site for binding to occur. These three different sequence requirements adds an additional level of species specificity which qPCR may lack between sympatric taxa (Wilcox et al., 2013). Our target species was Salmo salar, and the overall concept for the assay is described in Figure 1. We chose $S$. salar given its ecological and economic importance. S. salar have a high level of protection and, for example, are designated under Annex II of the European Union Water Framework Directive legislation. As a consequence, both the fish and its environment demands a high degree of assessment and reporting in respect of status (Chaput, 2012). Despite substantial controls on exploitation and increased environmental protection, numbers of wild $S$. salar continue to decline (Friedland et al., 2008). S. salar is also the primary farmed fish in Europe in terms of biomass and economic value (Dalvin, Glover, Sørvik, Seliussen, \& Taggart, 2010). S. salar often co-occur in waters with the closely related brown trout, $S$. trutta (Macqueen et al., 2017) so a highly specific assay is required for accurate detection from eDNA samples collected from their natural aquatic

This article is protected by copyright. All rights reserved. 
environments. The majority of eDNA studies to date target mitochondrial DNA (mtDNA) due to its high copy number compared to nuclear DNA (Rees, Maddison, Middleditch, Patmore, \& Gough, 2014) as well as its ability to resist degradation in the environment (Foran, 2006). Additionally, eDNA studies target short amplicons (90-120 base pairs (bp)) (Rees et al., 2014) increasing target detection when DNA may be highly degraded. For these reasons, our CRISPRCas assay design also targets $S$. salar mtDNA. The first experiment was to prove that our speciesspecific crRNA in combination with the Cas12a enzyme can differentiate between $S$. salar and $S$. trutta.

\section{Cas21a can distinguish between Salmo salar and Salmo trutta in species specific recombinant DNA sequences.}

We tested whether our S. salar Cas12a-crRNA could distinguish between S. salar and the closely related species $S$. trutta using recombinant versions of their respective DNA sequences. A 20bp S. salar target sequence in the mtDNA gene NADH dehydrogenase subunit 5, next to a 5'-TTTC-3' PAM site was selected, conforming to the consensus Cas12a 5'-TTTV-3' PAM site (Zetsche et al., 2015). In order to select the crRNA targeting region, complete mitochondrial sequences from $S$. salar, S. trutta and S. alpinus (SI Table S1) were aligned and visually scanned for regions whereby only $S$. salar contained the Cas12a specific T-rich PAM site. These species are closely related so assay design required maximum number of nucleotide differences. This specific PAM site was absent in $S$. trutta and $S$. alpinus and the subsequent target sequence conserved in $S$. salar, varied by two base pairs between $S$. salar and S. trutta. (Fig 2a). S. salar or S. trutta specific DNA containing plasmids were incubated with Cas12a-crRNA targeting the $S$. salar fragment and a single stranded DNA fluorophore-quencher (ssDNA FQ) reporter. Only upon target recognition and subsequent collateral cleavage by Cas12a nuclease should the reporter produce a signal. We show that our S. salar specific Cas12a-crRNA only produces a fluorescent signal when exposed to the recombinant $S$. salar DNA and not $S$. trutta DNA (Fig 2b). S. salar specific

This article is protected by copyright. All rights reserved. 
signal detection above background was detected down to a plasmid DNA concentration of $\geq 10^{-7}$

nM (Fig 2b).

\section{Cas12a coupled with RPA reaches attomolar sensitivity for its target $S$. salar sequence}

It is necessary to increase the sensitivity of the assay in order to achieve the detection of target species from eDNA. As previously reported (Chen et al., 2018; Gootenberg et al., 2017), the inclusion of a pre-amplification step can increase the sensitivity by several orders of magnitude. A major challenge with the adaptation of qPCR assays to a portable device is the need for cyclical high temperatures (Zanoli \& Spoto, 2013). Isothermal amplification methods, however, enable exponential amplification of DNA molecules at a single temperature. One isothermal method developed is RPA which uses enzymatic activity to amplify small amplicons $(<1.5 \mathrm{~Kb})$ rapidly and at low temperatures (Piepenburg, Williams, Stemple, \& Armes, 2006). This technique shows potential for on-site amplification of eDNA molecules due to the isothermal nature of the reaction creating a system which is easy to operate and requires less energy than PCR methods (Zanoli \& Spoto, 2013). Although RPA alone has been shown to be extremely sensitive (Wand, Bonney, Watson, Graham, \& Hewson, 2018), it can tolerate mismatches (Daher, Stewart, Boissinot, Boudreau, \& Bergeron, 2015) and therefore is not an optimal method to distinguish between closely related species such as $S$. salar and $S$. trutta. For this reason, it is important to couple such technology to a highly specific detection system.

We designed $S$. salar specific primers for RPA and coupled it with the S. salar Cas12a-crRNA detection assay. The additional pre-amplification step was tested on the $S$. salar specific recombinant DNA plasmids and showed an increase in sensitivity down to attomolar range (Fig 2c).

\section{Sensitivity and specificity maintained in the context of whole $S$. salar genome complexity}

This article is protected by copyright. All rights reserved. 
The sensitivity and specificity of this assay needed to be tested in a more complex genomic context i.e. using the entire $S$. salar and $S$. trutta genome as a template rather than a simple recombinant plasmid. Using DNA extracted from the tissue of $S$. salar and S. trutta we show that RPA coupled to CRISPR-Cas12a detected down to a concentration of $10^{-5} \mathrm{ng} / \mu \mathrm{l}$ in whole genomic $S$. salar DNA and showed no fluorescent signal with $S$. trutta genomic DNA (Fig 3). This demonstrates that the assay performance in a whole genomic context is both sensitive and specific for $S$. salar with no signal detection when $S$. trutta is used as template. The capability of the assay in its current form is to detect the presence or absence of the target species. Further work is required to explore the quantitative capabilities of the assay which involves optimising the concentrations of all molecular reagents at each step of the process and consideration of the kinetics of the Cas12a nuclease.

\section{RPA coupled to CRISPR-Cas12a can distinguish $S$. salar presence or absence from eDNA samples confirmed by qPCR and electrofishing}

The final test of this assay was to assess if it would work on eDNA samples acquired in the field that may contain amplification inhibitors and consist of a substantial proportion of degraded DNA (Taberlet et al., 2012). We used eDNA extracted from Irish freshwater river samples with known presence and absence of $S$. salar, confirmed previously using qPCR (SI Table S3) and electrofishing surveys (SI Table S2). Within a short-time frame $(<2.5 \mathrm{hr})$ S. salar was successfully detected from eDNA extracted from water samples with known presence of $S$. salar (Fig 4). Importantly, no fluorescence signal was seen in environmental samples where S. salar was not detected using electrofishing above migration barriers but known to contain $S$. trutta eDNA (SI) (Fig 4). While the quantitative aspects of this assay need to be explored further, our data in SI Table S3 indicates that we can detect the presence of $S$. salar DNA at equivalent concentrations to qPCR. The successful detection of $S$. salar in these samples shows the promise for using RPA coupled to CRISPR-Cas12a as an eDNA detection technique. Through careful design of species-specific primers (forward and reverse RPA primers) and a crRNA, the assay

This article is protected by copyright. All rights reserved. 
may be applied to any target organism to monitor species distribution (SI RPA-CRISPR-Cas12a Guide). This will make this assay a powerful tool for biodiversity monitoring in natural environments.

In summary, eDNA has already been used to monitor biodiversity in ancient and modern environments (Thomsen \& Willerslev, 2015) but the development of simplistic, specific and sensitive methods for on-site detection is needed to extend the application of eDNA. The next challenge is to adapt the assay to a device for on-site monitoring and a recently developed handheld fluorescent monitor for bacterial detection may prove suitable (Heery et al., 2016). One major recognised threat to biodiversity in aquatic systems is that of invasive species (Molnar, Gamboa, Revenga, \& Spalding, 2008). Detection of these species using traditional methods may be slow, enabling their establishment prior to detection. This threatens native biodiversity (Mooney \& Cleland, 2001) and can cause native species extinction (Gurevitch \& Padilla, 2004). The use of eDNA has already been shown to improve detection of invasive species (Dejean et al., 2012) due to the ability to detect organisms of low abundance. However, the development of RPA-CRISPR-Cas12a detection with an improved capability to differentiate closely related species and the potential for adaptation to a biosensor device, enhances the capabilities and utility of eDNA as an 'early warning' system for detection and management of any valuable, invasive or rare species and extends the reach of CRISPR-Cas technology to environmental monitoring.

\section{Acknowledgements}

This research is funded by the Irish Marine Institute as part of the Burrishoole Ecosystem Observatory Network 2020: BEYOND 2020 PBA/FS/16/02. We thank everyone in the Nutritional Genomics Group at Dublin City University for their support and advice with molecular techniques. The authors would like to thank staff from the Marine Institute Newport

This article is protected by copyright. All rights reserved. 
for project support and Inland Fisheries Ireland for electrofishing data from the Burren,

Dalligan and Delour Rivers that supported this research.

\section{References}

Atkinson, S., Carlsson, J. E. L., Ball, B., Egan, D., Kelly-Quinn, M., Whelan, K., \& Carlsson, J. (2018). A quantitative PCR-based environmental DNA assay for detecting Atlantic salmon ( Salmo salar L.). Aquatic Conservation: Marine and Freshwater Ecosystems, 28(5), 1238-1243. https://doi.org/10.1002/aqc.2931

Baker, C. S., Steel, D., Nieukirk, S., \& Klinck, H. (2018). Environmental DNA (eDNA) From the Wake of the Whales: Droplet Digital PCR for Detection and Species Identification. Frontiers in Marine Science, 5, 133. https://doi.org/10.3389/fmars.2018.00133

Barrangou, R., \& Doudna, J. A. (2016). Applications of CRISPR technologies in research and beyond. Nature Biotechnology, 34(9), 933-941. https://doi.org/10.1038/nbt.3659

Beans, C. (2018). Core Concept: Environmental DNA helps researchers track pythons and other stealthy creatures. Proceedings of the National Academy of Sciences of the United States of America, 115(36), 8843-8845. https://doi.org/10.1073/pnas.1811906115

Boothroyd, M., Mandrak, N. E., Fox, M., \& Wilson, C. C. (2016). Environmental DNA (eDNA) detection and habitat occupancy of threatened spotted gar (Lepisosteus oculatus). Aquatic Conservation: Marine and Freshwater Ecosystems, 26(6), 1107-1119. https://doi.org/10.1002/aqc.2617

Carlsson, J. E. L., Egan, D., Collins, P. C., Farrell, E. D., Igoe, F., \& Carlsson, J. (2017). A qPCR MGB probe based eDNA assay for European freshwater pearl mussel (Margaritifera margaritifera L.). Aquatic Conservation: Marine and Freshwater Ecosystems, 27(6), 13411344. https://doi.org/10.1002/aqc.2788

Chaput, G. (2012). Overview of the status of Atlantic salmon (Salmo salar) in the North Atlantic and trends in marine mortality. ICES Journal of Marine Science, 69(9), 1538-1548. https://doi.org/10.1093/icesjms/fss013

Chen, J. S., Ma, E., Harrington, L. B., Costa, M. Da, Tian, X., Palefsky, J. M., \& Doudna, J. A. (2018). CRISPR-Cas12a target binding unleashes indiscriminate single-stranded DNase activity. Science, 360(6387), 436-439. https://doi.org/10.1126/SCIENCE.AAR6245

Daher, R. K., Stewart, G., Boissinot, M., Boudreau, D. K., \& Bergeron, M. G. (2015). Influence of sequence mismatches on the specificity of recombinase polymerase amplification technology. Molecular and Cellular Probes, 29(2), 116-121. https://doi.org/10.1016/j.mcp.2014.11.005

Dalvin, S., Glover, K. A., Sørvik, A. G., Seliussen, B. B., \& Taggart, J. B. (2010). Forensic identification of severely degraded Atlantic salmon (Salmo salar) and rainbow trout (Oncorhynchus mykiss) tissues. Investigative Genetics, 1(1), 12. https://doi.org/10.1186/2041-2223-1-12

Deiner, K., Bik, H. M., Mächler, E., Seymour, M., Lacoursière-Roussel, A., Altermatt, F., ... Bernatchez, L. (2017). Environmental DNA metabarcoding: Transforming how we survey animal and plant communities. Molecular Ecology, 26(21), 5872-5895. https://doi.org/10.1111/mec.14350

This article is protected by copyright. All rights reserved. 
Dejean, T., Valentini, A., Duparc, A., Pellier-Cuit, S., Pompanon, F., Taberlet, P., \& Miaud, C. (2011). Persistence of Environmental DNA in Freshwater Ecosystems. PLoS ONE, 6(8), e23398. https://doi.org/10.1371/journal.pone.0023398

Dejean, T., Valentini, A., Miquel, C., Taberlet, P., Bellemain, E., \& Miaud, C. (2012). Improved detection of alien invasive species through environmental DNA barcoding: the example of the American bullfrog Lithobates catesbeianus. Journal of Applied Ecology, 49(4), 953-959.

DeLong, E. F. (2005). Microbial community genomics in the ocean. Nature Reviews Microbiology, 3(6), 459-469. https://doi.org/10.1038/nrmicro1158

Ficetola, G. F., Miaud, C., Pompanon, F., \& Taberlet, P. (2008). Species detection using environmental DNA from water samples. Biology Letters, 4(4), 423-425. https://doi.org/10.1098/rsbl.2008.0118

Fonfara, I., Richter, H., Bratovič, M., Le Rhun, A., \& Charpentier, E. (2016). The CRISPR-associated DNA-cleaving enzyme Cpf1 also processes precursor CRISPR RNA. Nature, 532(7600), 517-521. https://doi.org/10.1038/nature17945

Foran, D. R. (2006). Relative Degradation of Nuclear and Mitochondrial DNA: An Experimental Approach*. Journal of Forensic Sciences, 51(4), 766-770. https://doi.org/10.1111/j.15564029.2006.00176.x

Friedland, K. D., MacLean, J. C., Hansen, L. P., Peyronnet, A. J., Karlsson, L., Reddin, D. G., ... McCarthy, J. L. (2008). The recruitment of Atlantic salmon in Europe. ICES Journal of Marine Science, 66(2), 289-304. https://doi.org/10.1093/icesjms/fsn210

Gargan, L. M., Morato, T., Pham, C. K., Finarelli, J. A., Carlsson, J. E. L., \& Carlsson, J. (2017). Development of a sensitive detection method to survey pelagic biodiversity using eDNA and quantitative PCR: a case study of devil ray at seamounts. Marine Biology, 164(5), 112. https://doi.org/10.1007/s00227-017-3141-x

Gootenberg, J. S., Abudayyeh, O. O., Kellner, M. J., Joung, J., Collins, J. J., \& Zhang, F. (2018). Multiplexed and portable nucleic acid detection platform with Cas13, Cas12a, and Csm6. Science, 360(6387), 439-444. https://doi.org/10.1126/science.aaq0179

Gootenberg, J. S., Abudayyeh, O. O., Lee, J. W., Essletzbichler, P., Dy, A. J., Joung, J., ... Zhang, F. (2017). Nucleic acid detection with CRISPR-Cas13a/C2c2. Science, 356(6336), 438-442. https://doi.org/10.1126/science.aam9321

Guisan, A., Tingley, R., Baumgartner, J. B., Naujokaitis-Lewis, I., Sutcliffe, P. R., Tulloch, A. I. T., ... Buckley, Y. M. (2013). Predicting species distributions for conservation decisions. Ecology Letters, 16(12), 1424-1435. https://doi.org/10.1111/ele.12189

Gurevitch, J., \& Padilla, D. K. (2004). Are invasive species a major cause of extinctions? Trends in Ecology \& Evolution, 19(9), 470-474. https://doi.org/10.1016/J.TREE.2004.07.005

Heery, B., Briciu-Burghina, C., Zhang, D., Duffy, G., Brabazon, D., O'Connor, N., \& Regan, F. (2016). ColiSense, today's sample today: A rapid on-site detection of $\beta$-d-Glucuronidase activity in surface water as a surrogate for E. coli. Talanta, 148, 75-83.

https://doi.org/10.1016/J.TALANTA.2015.10.035

Jerde, C. L., Mahon, A. R., Chadderton, W. L., \& Lodge, D. M. (2011). "Sight-unseen" detection of rare aquatic species using environmental DNA. Conservation Letters, 4(2), 150-157. https://doi.org/10.1111/j.1755-263X.2010.00158.x

Li, C., Wen, A., Shen, B., Lu, J., Huang, Y., \& Chang, Y. (2011). FastCloning: a highly simplified,

This article is protected by copyright. All rights reserved. 
purification-free, sequence- and ligation-independent PCR cloning method. $B M C$ Biotechnology, 11(1), 92. https://doi.org/10.1186/1472-6750-11-92

Macqueen, D. J., Primmer, C. R., Houston, R. D., Nowak, B. F., Bernatchez, L., Bergseth, S., ... Yáñez, J. M. (2017). Functional Annotation of All Salmonid Genomes (FAASG): an international initiative supporting future salmonid research, conservation and aquaculture. $B M C$ Genomics, 18(1), 484. https://doi.org/10.1186/s12864-017-3862-8

Magnuson, J. J., Benson, B. J., \& Mclain, A. S. (1994). Insights on species richness and turnover from long-term ecological research: Fishes in north temperate lakes. Integrative and Comparative Biology, 34(3), 437-451. https://doi.org/10.1093/icb/34.3.437

Möller, E. M., Bahnweg, G., Sandermann, H., \& Geiger, H. H. (1992). A simple and efficient protocol for isolation of high molecular weight DNA from filamentous fungi, fruit bodies, and infected plant tissues. Nucleic Acids Research, 20(22), 6115-6116.

Molnar, J. L., Gamboa, R. L., Revenga, C., \& Spalding, M. D. (2008). Assessing the global threat of invasive species to marine biodiversity. Frontiers in Ecology and the Environment, 6(9), 485-492. https://doi.org/10.1016/j.jallcom.2015.08.157

Mooney, H. A., \& Cleland, E. E. (2001). The evolutionary impact of invasive species. Proceedings of the National Academy of Sciences of the United States of America, 98(10), 5446-5451. https://doi.org/10.1073/pnas.091093398

Piepenburg, O., Williams, C. H., Stemple, D. L., \& Armes, N. A. (2006). DNA detection using recombination proteins. PLoS Biology, 4(7), e204. https://doi.org/10.1371/journal.pbio.0040204

Rees, H. C., Maddison, B. C., Middleditch, D. J., Patmore, J. R. M., \& Gough, K. C. (2014). REVIEW: The detection of aquatic animal species using environmental DNA - a review of eDNA as a survey tool in ecology. Journal of Applied Ecology, 51(5), 1450-1459. https://doi.org/10.1111/1365-2664.12306

Renshaw, M. A., Olds, B. P., Jerde, C. L., McVeigh, M. M., \& Lodge, D. M. (2015). The room temperature preservation of filtered environmental DNA samples and assimilation into a phenol-chloroform-isoamyl alcohol DNA extraction. Molecular Ecology Resources, 15(1), 168-176. https://doi.org/10.1111/1755-0998.12281

Rusch, J. C., Hansen, H., Strand, D. A., Markussen, T., Hytterød, S., \& Vrålstad, T. (2018). Catching the fish with the worm: a case study on eDNA detection of the monogenean parasite Gyrodactylus salaris and two of its hosts, Atlantic salmon (Salmo salar) and rainbow trout (Oncorhynchus mykiss). Parasites \& Vectors, 11(1), 333. https://doi.org/10.1186/s13071018-2916-3

Shokralla, S., Spall, J. L., Gibson, J. F., \& Hajibabaei, M. (2012). Next-generation sequencing technologies for environmental DNA research. Molecular Ecology, 21(8), 1794-1805. https://doi.org/10.1111/j.1365-294X.2012.05538.x

Snyder, D. (2003). Invite overview: conclusions from a review of electrofishing and its harmful effects on fish. Reviews in Fish Biology and Fisheries, 13, 445-453.

Taberlet, P., Coissac, E., Pompanon, F., Brochmann, C., \& Willerslev, E. (2012). Towards nextgeneration biodiversity assessment using DNA metabarcoding. Molecular Ecology, 21(8), 2045-2050. https://doi.org/10.1111/j.1365-294X.2012.05470.x

The Standing Scientific Committee on Salmon. (2016). The Status of Irish Salmon Stocks in 2015, with Precautionary Catch Advice for 2016.

This article is protected by copyright. All rights reserved. 
Thomsen, P. F., Kielgast, J., Iversen, L. L., Møller, P. R., Rasmussen, M., \& Willerslev, E. (2012). Detection of a Diverse Marine Fish Fauna Using Environmental DNA from Seawater Samples. PLoS ONE, 7(8), e41732. https://doi.org/10.1371/journal.pone.0041732

Thomsen, P. F., Kielgast, J., Iversen, L. L., Wiuf, C., Rasmussen, M., Gilbert, M. T. P., ... Willerslev, E. (2012). Monitoring endangered freshwater biodiversity using environmental DNA. Molecular Ecology, 21(11), 2565-2573. https://doi.org/10.1111/j.1365294X.2011.05418.x

Thomsen, P. F., \& Willerslev, E. (2015). Environmental DNA - An emerging tool in conservation for monitoring past and present biodiversity. Biological Conservation, 183, 4-18. https://doi.org/10.1016/J.BIOCON.2014.11.019

Turner, C. R., Uy, K. L., \& Everhart, R. C. (2015). Fish environmental DNA is more concentrated in aquatic sediments than surface water. Biological Conservation, 183, 93-102. https://doi.org/10.1016/J.BIOCON.2014.11.017

Uthicke, S., Lamare, M., \& Doyle, J. R. (2018). eDNA detection of corallivorous seastar (Acanthaster cf. solaris) outbreaks on the Great Barrier Reef using digital droplet PCR. Coral Reefs, 37(4), 1229-1239. https://doi.org/10.1007/s00338-018-1734-6

Wand, N., Bonney, L. C., Watson, R. J., Graham, V., \& Hewson, R. (2018). Point-of-care diagnostic assay for the detection of zika virus using the recombinase polymerase amplification method. Journal of General Virology, 99(8), 1012-1026.

https://doi.org/10.1099/jgv.0.001083

Ward, R. D., Zemlak, T. S., Innes, B. H., Last, P. R., \& Hebert, P. D. . (2005). DNA barcoding Australia's fish species. Philosophical Transactions of the Royal Society B: Biological Sciences, 360(1462), 1847-1857. https://doi.org/10.1098/rstb.2005.1716

Wilcox, T. M., McKelvey, K. S., Young, M. K., Jane, S. F., Lowe, W. H., Whiteley, A. R., \& Schwartz, M. K. (2013). Robust Detection of Rare Species Using Environmental DNA: The Importance of Primer Specificity. PLoS ONE, 8(3), e59520. https://doi.org/10.1371/journal.pone.0059520

Willerslev, E., Cappellini, E., Boomsma, W., Nielsen, R., Hebsgaard, M. B., Brand, T. B., ... Collins, M. J. (2007). Ancient biomolecules from deep ice cores reveal a forested southern Greenland. Science (New York, N.Y.), 317(5834), 111-114. https://doi.org/10.1126/science.1141758

WWF. (2018). Living Planet Report - 2018: Aiming Higher. Gland, Switzerland.

Yamano, T., Nishimasu, H., Zetsche, B., Hirano, H., Slaymaker, I. M., Li, Y., ... Nureki, O. (2016). Crystal Structure of Cpf1 in Complex with Guide RNA and Target DNA. Cell, 165(4), 949962. https://doi.org/10.1016/j.cell.2016.04.003

Zanoli, L. M., \& Spoto, G. (2013). Isothermal amplification methods for the detection of nucleic acids in microfluidic devices. Biosensors, 3(1), 18-43. https://doi.org/10.3390/bios3010018

Zetsche, B., Gootenberg, J. S., Abudayyeh, O. O., Slaymaker, I. M., Makarova, K. S., Essletzbichler, P., ... Zhang, F. (2015). Cpf1 Is a Single RNA-Guided Endonuclease of a Class 2 CRISPR-Cas System. Cell, 163(3), 759-771. https://doi.org/10.1016/j.cell.2015.09.038

Zhang, C., \& Xing, D. (2007). Miniaturized PCR chips for nucleic acid amplification and analysis: latest advances and future trends. Nucleic Acids Research, 35(13), 4223-4237. https://doi.org/10.1093/nar/gkm389

This article is protected by copyright. All rights reserved. 


\section{Data Accessibility}

All data pertaining to this work is contained in the main text and the Supplementary Information file.

Author contributions: MAW, FR, JOG, PMcG, EJ, APMCD designed the research; MAW performed the experiments and analysed the data; BB, JC provided eDNA samples, qPCR and electrofishing data; EdeE provided data and fieldwork support; MAW, APMCD interpreted data and wrote the paper; all authors contributed to and approved the final draft.

The authors declare no conflict of interest

\section{Figure Legends}

Figure 1: Overview of RPA-CRISPR-Cas12a detection. Water sample collected and filtered before DNA extraction. Target DNA is amplified using isothermal Recombinase Polymerase Amplification (RPA) prior to CRISPR-Cas12a mediated fluorescence detection of target using a ssDNA fluorophore-quencher (FQ) Reporter. PAM, Protospacer Adjacent Motif; NTS, Non-Target Strand; TS, Target Strand

Figure 2: Species specific crRNA proceeded by a 5'-TTTV-3' PAM site enables detection of recombinant target DNA. (a) Alignment of crRNA targeting site in S. salar and S. trutta showing PAM sequence, base pair differences and polymorphic bases. (b) Background subtracted fluorescence time course of Cas12a preassembled with a crRNA targeting $S$. salar in the presence of a recombinant plasmid containing a $S$. salar or $S$. trutta DNA fragment and a ssDNA FQ reporter. Fluorescence measurements were taken every 30 seconds for 2 hours at $37^{\circ} \mathrm{C}$. Error bars are mean \pm standard deviation, where $n=3$ (c) Titration of $S$. salar recombinant plasmid detected with Cas12a alone (without pre-amplification of target DNA) and with RPACRISPR-Cas12a. Alone Cas12a shows detection above background at $10^{-7} \mathrm{nM}$ while coupling CRISPR-Cas12a to RPA achieved attomolar sensitivity detecting down to $10^{-13} \mathrm{nM}$. Error bars are mean \pm standard deviation, where $n=3$. Threshold value is $3 \times$ standard deviation of background fluorescence (samples with no DNA template added).

Figure 3: Sensitivity and specificity of assay is maintained in a whole genomic context. The coupled RPA-CRISPR-Cas12a assay was applied to a dilution series of DNA extracted from $S$. salar tissue $\left(4-4 \times 10^{-6} \mathrm{ng} / \mu \mathrm{l}\right)$ and DNA extracted from $S$. trutta tissue $(5.75 \mathrm{ng} / \mu \mathrm{l})$. The assay detected $S$. salar down to a concentration of $10^{-5} \mathrm{ng} / \mu \mathrm{l}$ and importantly showed no detection of $S$. trutta. Error bars are mean \pm standard deviation, where $n=3$. Threshold value is $3 \mathrm{x}$ standard deviation of background fluorescence (samples with no DNA template added). Level of significant difference from background, based on a one tailed t-test assuming unequal variances where ${ }^{*} \mathrm{p} \leq 0.05,{ }^{* *} \mathrm{p} \leq 0.01$ and ${ }^{* * *} \mathrm{p} \leq 0.001$

Figure 4: RPA coupled to CRISPR-Cas12a enables detection of $S$. salar from eDNA extracted from freshwater samples. $S$. salar presence confirmed in rivers Burren, Delour and downstream Srahrevagh. S. salar absence confirmed in Dalligan and upstream Srahrevagh. Note: S. trutta was present in all samples but not detected. Positive control: $S$. salar DNA from tissue

This article is protected by copyright. All rights reserved. 
extract. Negative control: no DNA template added. (+) $S$. salar confirmed present by electrofishing surveys and qPCR. (-) S. salar confirmed absent by electrofishing and qPCR. Error bars are mean \pm standard deviation, where $n=3$. Threshold value is $3 \times$ standard deviation of background fluorescence (samples with no DNA template added). Level of significant difference from background, based on a one tailed t-test assuming unequal variances where ${ }^{*} \mathrm{p} \leq 0.05$, ${ }^{* *} \mathrm{p} \leq 0.01$ and ${ }^{* * *} \mathrm{p} \leq 0.001$

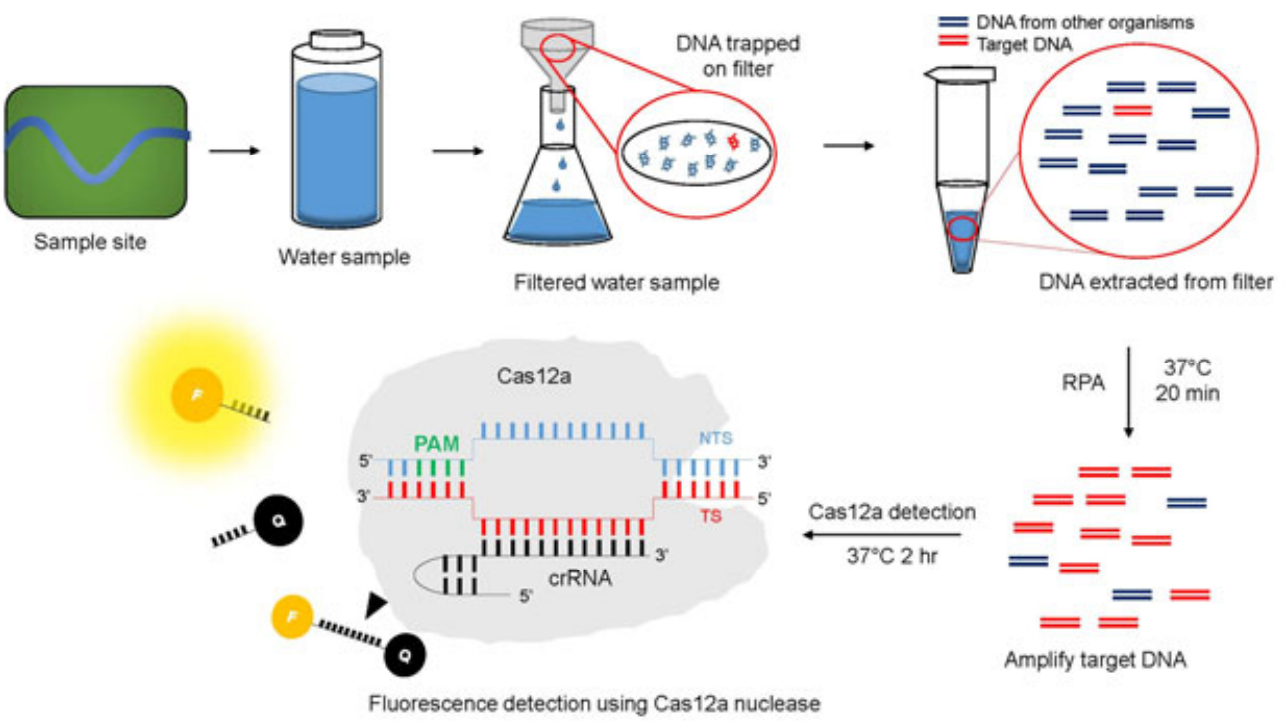

This article is protected by copyright. All rights reserved. 

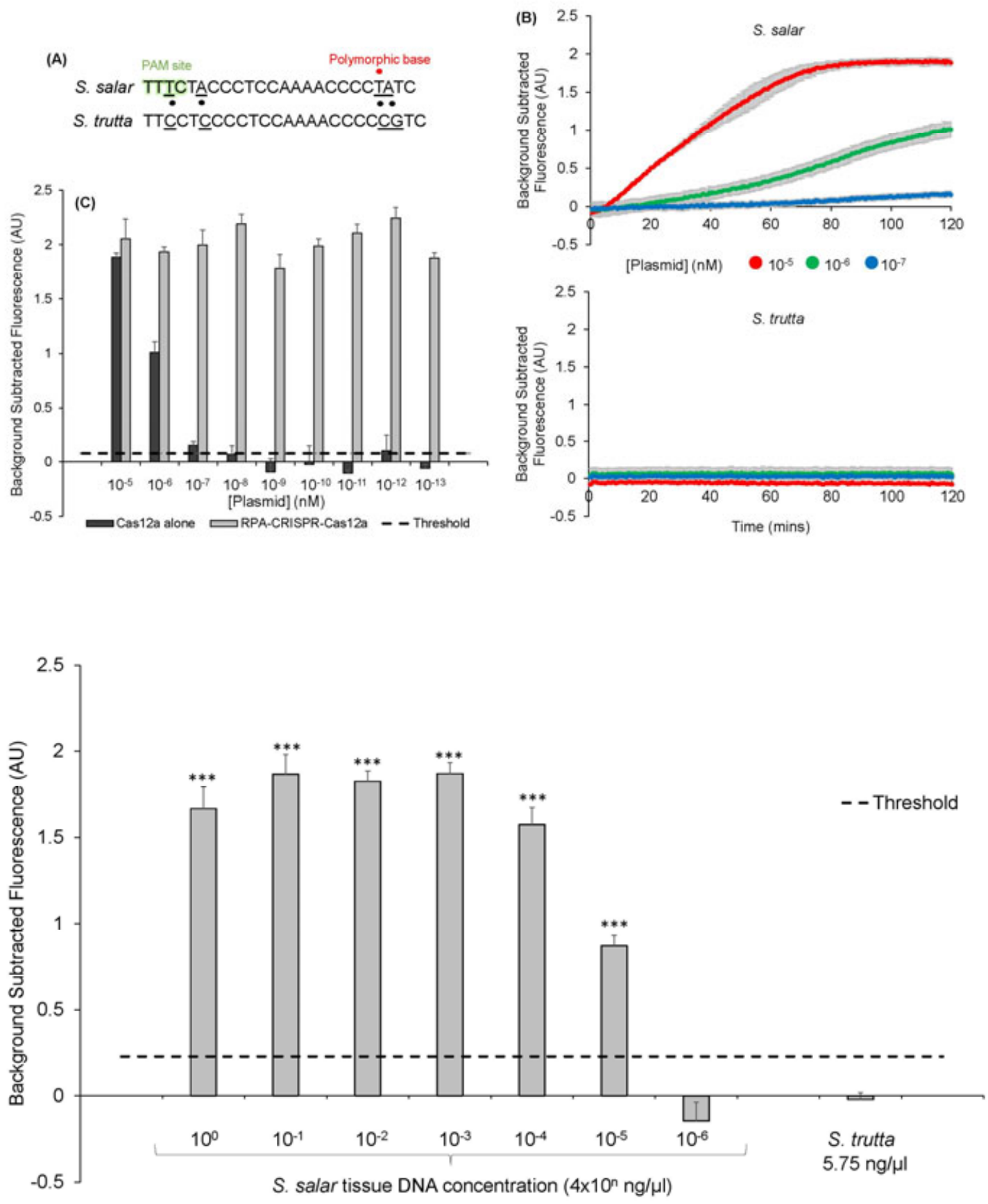

This article is protected by copyright. All rights reserved. 


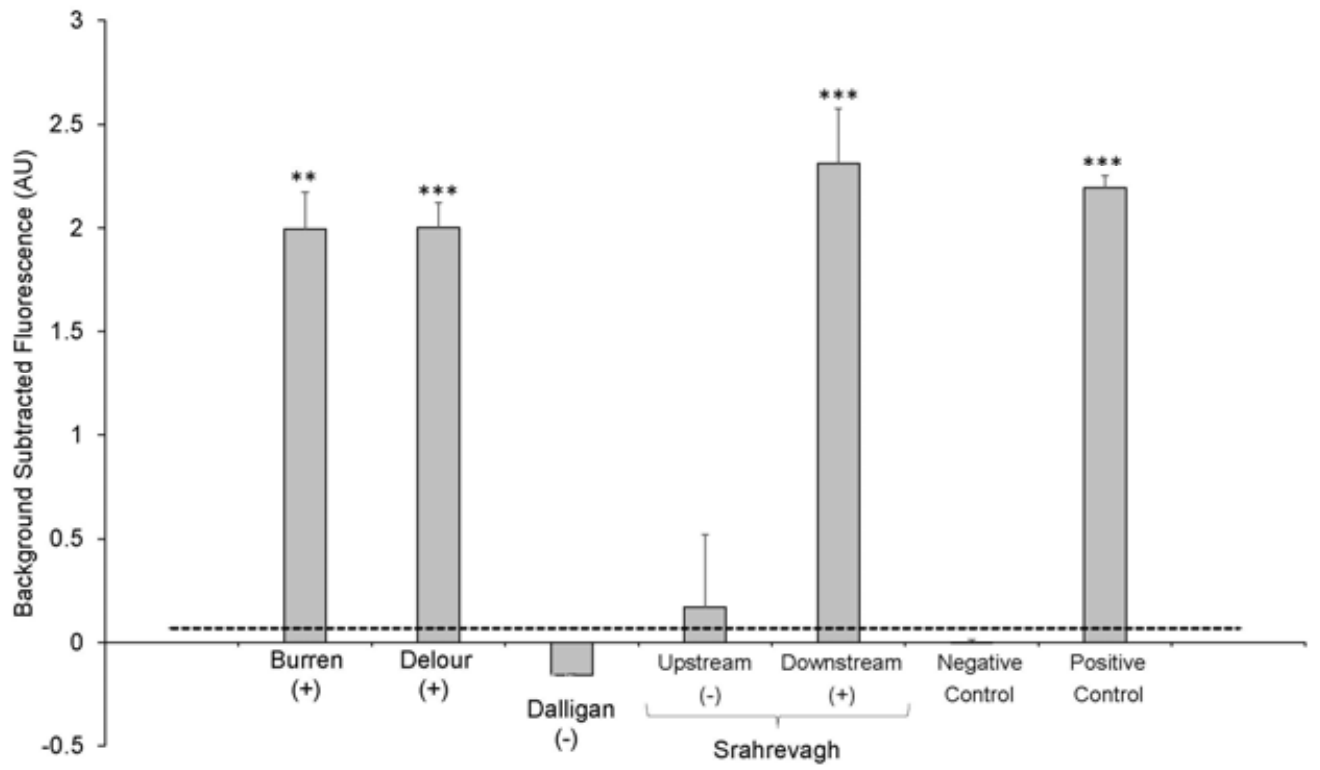

This article is protected by copyright. All rights reserved. 